\title{
Late Diagnosis of Oral Melanoma
}

\author{
Diagnóstico Tardío de Melanoma Oral
}

\author{
Lucas Alves da Mota Santana'; John Lennon Silva Cunha; Thiago Santana Ribeiro'; \\ Celeste Sánchez-Romero ${ }^{3}$; Cleverson Luciano Trento'; Antônio Carlos Marqueti'; \\ Ricardo Luiz Cavalcanti de Albuquerque-Júnior ${ }^{2}$ \& Sílvia Ferreira de Sousa ${ }^{4}$
}

\begin{abstract}
SANTANA, L. A. M.; CUNHA, J. L. S.; RIBEIRO, T. S.; SÁNCHEZ-ROMERO, C.; TRENTO, C. L.; MARQUETI, A. C.; ALBUQUERQUE-JÚNIOR, R. L. C. \& SOUSA, S. F. Late diagnosis of oral melanoma. Int. J. Odontostomat., 13(2):230-234, 2019.

ABSTRACT: Oral melanoma $(\mathrm{OM})$ is an extremely rare and aggressive malignancy. A 67-year-old patient presented with complains of a slightly symptomatic spot in the mouth since the past 2 years. Extraoral examination revealed left cervical lymphadenopathy, and intraoral examination a blue-black multinodular sessile mass, with irregular margins, involving the attached gingiva of teeth 27 and 28 , extending to vestibular sulcus and hard palate, measuring approximately $3.5 \mathrm{~cm}$. The lesion presented focal areas of ulceration. Panoramic radiograph did not show bone involvement. The main diagnostic hypothesis was oral melanoma. Microscopic findings of the incisional biopsy revealed a proliferation of densely pigmented pleomorphic cells, invading the subepithelial connective tissue in sheets or nests showing an organoid pattern. Immunopositivity for S-100, Melan-A and HMB-45 confirmed the diagnosis of melanoma. The patient was referred to an oncology hospital in which multiple metastases were detected, and the patient was subjected to palliative care. Herein we report an OM in advanced clinical stage, and discuss the clinical, morphological and immunohistochemical diagnostic criteria with emphasis on the importance of early diagnosis.
\end{abstract}

KEY WORDS: head and neck cancer, melanoma, oral melanoma.

\section{INTRODUCTION}

Primary melanoma of the oral cavity is quite rare and corresponds to only 0.4 to $1.8 \%$ of all melanomas, and about $0.5 \%$ of all malignancies of the oral cavity, with an incidence of 1.2 cases per 10 million individuals per year (Deyhimi et al., 2017). Oral melanoma (OM) tends to occur in adults between the fifth and sixth decades of life. The hard palate and upper alveolar ridge are the anatomical sites more frequently involved (El-Naggar et al., 2017).

In contrast to cutaneous melanoma, the pathogenesis of OM is poorly understood (Ascierto et al., 2017). It is believed that OM originates from the malignant transformation of melanocytic cells present in the oral mucosa epithelium (Smith et al., 2016; Topic et al., 2017). There are no etiological factors clearly associated to the development of OM; however, exist association with BRAF, RAS, KIT and BAP1 mutations (El-Naggar et al.; Hsieh et al., 2017).
This case report presents clinical, histopathological, and immunohistochemical features of an extensive oral melanoma lately diagnosed, in a 67 -year-old male, emphasizing the importance of an early diagnosis.

\section{CASE REPORT}

A 67-year-old patient was referred with chief complaint of swelling in the mouth. Anamnesis revealed that the patient worked in farming, was non-smoker and non-alcohol drinker. Previous medical history included hypertension and type 2 diabetes. In extraoral examination, a left submandibular lymph node was palpable, non-tender, and firm in consistency. The intraoral examination revealed an asymptomatic multinodular dark-colored swelling in the left maxillary vestibule and

\footnotetext{
${ }^{1}$ Department of Dentistry, Biological Sciences and Health Center, Universidade Federal de Sergipe (UFS), Aracaju, SE, Brazil.

2 Laboratory of Morphology and Experimental Pathology, Institute of Technology and Research, Tiradentes University (UNIT), Aracaju, SE, Brazil.

${ }^{3}$ Oral Pathology Section, Department of Oral Diagnosis, Piracicaba Dental School, University of Campinas (UNICAMP), Piracicaba, SP, Brazil.

${ }^{4}$ Department of Oral Surgery and Pathology, School of Dentistry, Universidade Federal de Minas Gerais, Belo Horizonte, Brazil.
} 
alveolar mucosa, extending to the hard palate with approximately $3.5 \mathrm{~cm}$ in diameter (Fig. 1). The patient referred an evolution time of 2 years. The lesion was sessile with poorly-defined margins and no hardening of surround tissues. The associated teeth were vital and demonstrated mobility and buccal displacement. A panoramic radiograph did not show bone involvement (Fig. 2). Based on clinical features, the diagnostic hypothesis was $\mathrm{OM}$ and an incisional biopsy was performed under local anesthesia. Two soft tissue fragments were submitted for pathological analysis.

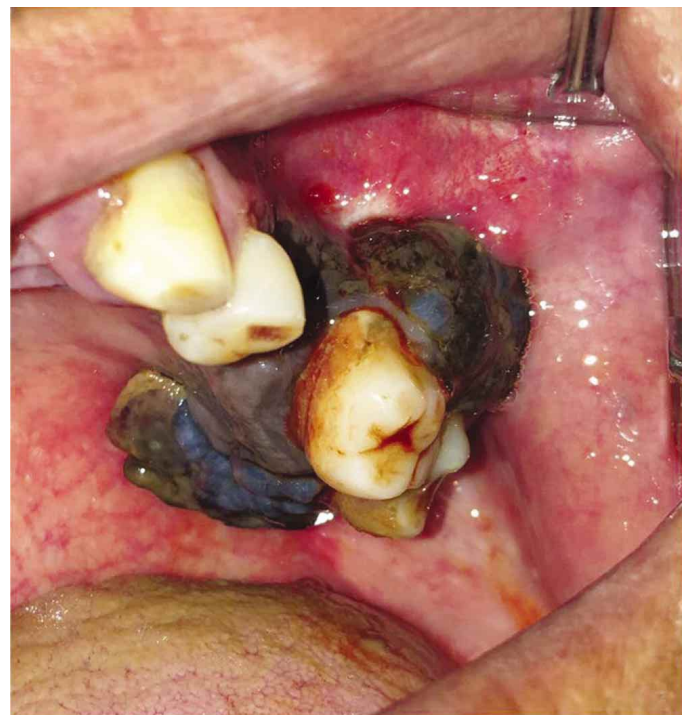

Fig. 1. Clinical image of the tumor. Intraoral photograph showing an ulcerated, blue-black, multinodular elevated lesion in the posterior left maxilla. The lesion extends across the hard palate and onto the attached vestibular gingiva of teeth 27 and 28 and vestibular sulcus.
On gross examination, the largest specimen measured $0.7 \times 0.6 \times 0.2 \mathrm{~cm}$ and the other $0,6 \times 0,5 \times$ $0.4 \mathrm{~cm}$. Both of them were ovoid in shape, with rubberconsistency, showing some darker areas than the rest of the specimen (Fig. 3). On histopathological examination, H\&E sections showed a diffuse proliferation of sheets and nests of melanocytic cells arranged in an organoid pattern, with abundant melanin production (Figs. 4A-D). The neoplastic cells presented ovoid nuclei, pale cytoplasm containing brown granules compatible with melanin. Variable degrees of cellular pleomorphism and nuclear hyperchromatism as well as proeminent amphophilic nucleolus were observed

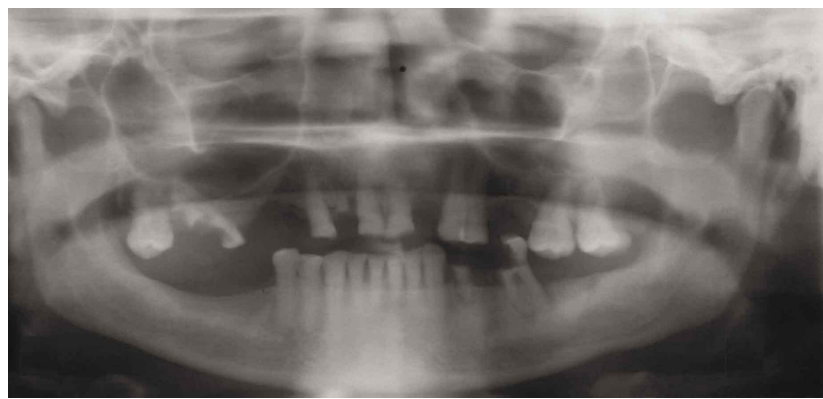

Fig. 2. Radiographic image. No signs of bone involvement were detected on panoramic radiography.

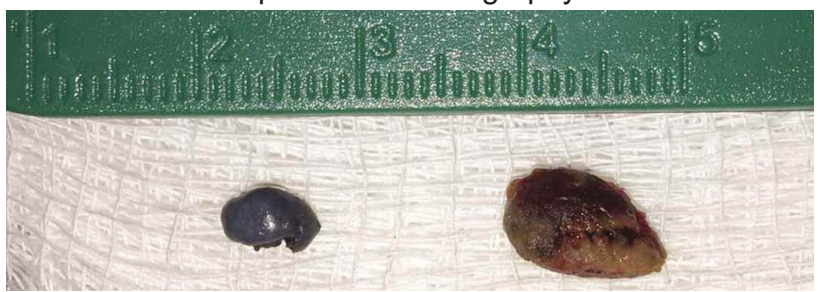

Fig. 3. Gross features of oral melanoma after incisional biopsy. Two ovoid soft tissue fragments were obtained, one showing blue-black color and other brownish.
A

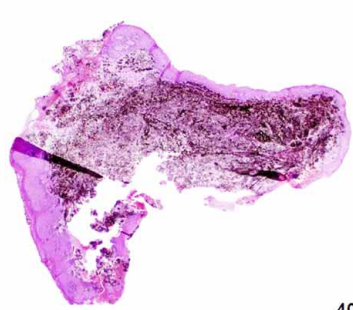

$400 \mu \mathrm{m}$

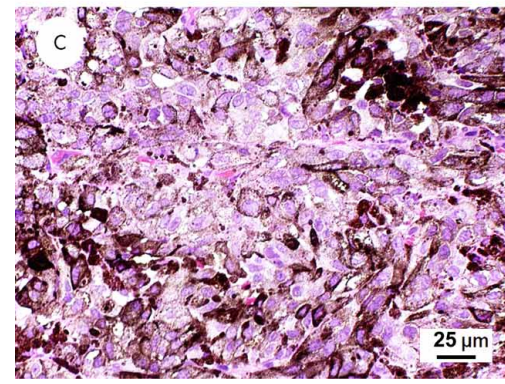

B

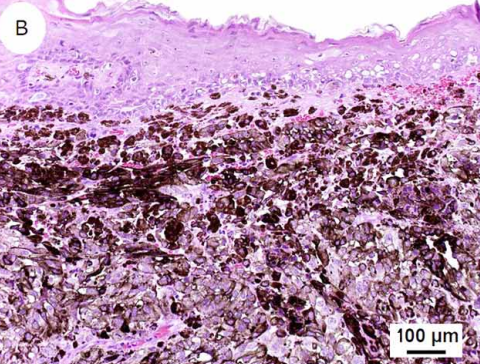

D

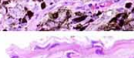


SANTANA, L. A. M.; CUNHA, J. L. S.; RIBEIRO, T. S.; SÁNCHEZ-ROMERO, C.; TRENTO, C. L.; MARQUETI, A. C.; ALBUQUERQUE-JÚNIOR, R. L. C. \& SOUSA, S. F. Late diagnosis of oral melanoma. Int. J. Odontostomat., 13(2):230-234, 2019.

(Fig. 4C). The lesion was lined with parakeratinized stratified squamous epithelium exhibiting atypical and pleomorphic melanocytes in the basal and suprabasal layers (junctional activity) (Fig. 4D). An area of ulceration with extravasation of erythrocytes was also observed. Mitotic activity was intense, and atypical mitotic figures were often seen. Additionally, scarce lymphocytic inflammatory response was present surrounding tumor cells. Subsequently, immunohistochemical analysis was performed for confirmation of the tumor cells phenotype, which were strongly and diffusely positive for MELAN-A (Fig. 5A), HMB-45 (Fig. 5B), and S-100 (Fig. 5C) protein. Due to the prominent presence of melanin, prior the immunohistochemical reactions, bleaching of melanin with hydrogen peroxide was performed to use DAB as chromogen (Liu et al., 2013). Based on the clinical, morphologic and immunohistochemical findings, the final diagnosis was OM.

The patient was referred to an oncology service where imaging studies, such as computed tomography and chest radiograph, was performed and revealed pulmonary and hepatic metastases. TNM staging for present case was stage IV (T4aN1bM1b). The patient and his/her family were informed about the diagnosis, therapeutic options and prognosis of the condition. However, due to the advanced stage of the disease, presence of metastases and health state of the patient, no treatment was indicated and he or she was subjected to palliative care.

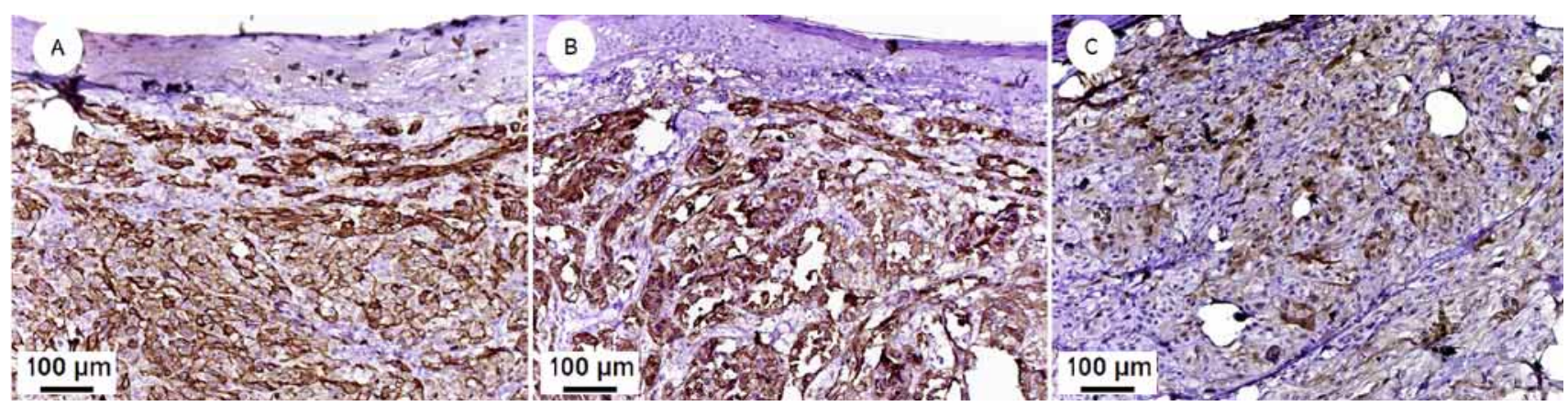

Fig. 5. Immunohistochemical features. Tumor cells showing positive staining for (A) HMB-45, (B) Melan-A, and (C) S-100 protein (Immunoperoxidase).

\section{DISCUSSION}

The etiology of OM remains unknown and seems to be different from cutaneous melanomas, due to the lack of relation with risk factors, such as exposure to ultraviolet radiation, family history and association with atypical nevi, conditions favoring the onset of melanoma of skin (El-Naggar et al.).

Clinically, individuals affected by OM most often may present different color nuances in the same lesion (El-Naggar et al.; Ascierto et al.). Other complaints such as pain, ulceration, bleeding, tooth mobility, and paresthesia may be observed. The hard palate and upper alveolar ridge are the most affected sites by OM; however, cases involving buccal mucosa, tongue, and floor of the mouth are reported (Topic et al.; Moshe et al., 2018). According to these data, in our case, the clinical presentation was initially asymptomatic and the patient sought a specialized service only after the significant growth of the lesion. In fact, several cases published in the literature emphasize that due to the asymptomatic behavior of $\mathrm{OM}$ in their initial phases, there is a frequent delay in the seek professional assistance, which contributes to the tumors to be often diagnosed in advanced stages, contributing to a poor prognosis (Ascierto et al.; Smith et al.; Topic et al.).

Differential diagnosis is wide and includes a spectrum of reactive, benign, and malignant lesions, with distinct biological behaviors (Caldeira et al., 2010; Gondak et al., 2012; El-Naggar et al.; Eachempati et al., 2018). However, in our case, the classic clinical presentation rules out any possibility of doubtful interpretation of the diagnosis, differing clearly from the pigmented lesions found in Peutz-Jeghers syndrome, Addison's disease, Kaposi's sarcoma, amalgam tattoo, 
nevus, melanotic pigmentation, or melanoacanthoma. These lesions may be detected by the patient or during a routine dental exam. The clinical history, symmetry, margins and color uniformity are essential in determining the clinical differential diagnosis (Gondak et al.; El-Naggar et al.).

Histologically, melanoma is known for its distinct ability to mimic a number of neoplasms, because of its heterogeneous histopathological presentation, besides the absence of melanin deposition seen in some cases. In this situation, the histopathologic differential diagnosis varies immensely and the morphological differential diagnosis includes numerous spindle cell malignant tumors, epithelioid malignant tumors (such as epithelioid sarcoma), round cell tumors, clear cell malignant tumors (such as mucoepidermoid carcinoma, renal cell carcinoma), and metastatic lesions (El-Naggar et al.; Smith et al.; Topic et al.). Characteristically, melanoma cells exhibit a prominent central, single, and amphophilic nucleoli, however, the tumor cells may be arranged in different architectural patterns, such as organoid, pagetoid, alveolar, storiform or fascicular growths, or as a combination of these patterns. Intracellular and extracellular melanin can be present in varying quantities. Most of these features were observed in the present case, supporting the diagnosis of melanoma. Also, necrosis and perineural and perivascular invasions may be seen (Gondak et al.; El-Naggar et al.).

When melanin pigmentation is present, as in our case, OM usually can be easily diagnosed by a morphological analysis (Ascierto et al.). However, when the lesion is amelanotic, the immunohistochemistry analysis is necessary to establish the correct diagnosis (Smith et al.). In both situations, positive immunohistochemical reactions for Melan-A, HMB-45 and S-100 confirm the diagnosis (Liu et al.), as occurred in our case.

OMs are highly aggressive neoplasms with difficult therapeutic management, and the patients' clinical approach is usually determined by the presentation of the lesion considering the surgical possibilities and the quality of life of the patients. OM treatment includes radical surgery, cryotherapy, chemotherapy and radiotherapy, used individually or in combination (Schaefer et al., 2017). In general, the prognosis of patients is very unfavorable, with survival rates lower than those described for patients with cutaneous melanoma (El-Naggar et al.; Schaefer et al.).
Factors associated with worse prognosis include tumor polymorphism, vascular invasion, advanced age, positive surgical margins, deep infiltration, and necrosis (El-Naggar et al.; Ascierto et al.). Local recurrences are reported in more than $50 \%$ of cases, while 5-year survival for patients affected by oral melanomas is as low as $15 \%$, which makes early diagnosis imperative (Schaefer et al.).

Despite the classical clinical and histopathological features in the present case, our patient was diagnosed with advanced disease and he was subjected to palliative care. Even with rapid advances in treatment modalities, OM remains a lifethreatening disease with no marked improvement in prognosis and survival rates. This is mainly attributed to late diagnosis (Gondak et al.). Thus, it is essential to perform histopathological evaluation of any suspicious pigmented lesion, since the early diagnosis and surgical removal are crucial for a favorable prognosis.

SANTANA, L. A. M.; CUNHA, J. L. S.; RIBEIRO, T. S.; SÁNCHEZ-ROMERO, C.; TRENTO, C. L.; MARQUETI, A. C.; ALBUQUERQUE-JÚNIOR, R. L. C. \& SOUSA, S. F. Diagnóstico tardío de melanoma oral. Int. J. Odontostomat., 13(2):230-234, 2019.

RESUMEN: El melanoma oral (MO) es una malignidad extremadamente rara y agresiva. Un paciente de 67 años acudió a consulta con la queja de una mancha intraoral ligeramente sintomática, presente desde hace dos años. Al examen clínico extraoral, se encontró adenopatía cervical del lado izquierdo, y al examen intraoral, se observó una masa sésil multinodular de color negro azulado, focalmente ulcerada, con bordes irregulares, afectando la encía de los dientes 27 y 28 , extendiéndose hasta el surco vestibular y el paladar duro, midiendo aproximadamente $3,5 \mathrm{~cm}$. La radiografía panorámica no mostró involucramiento óseo. La principal hipótesis diagnóstica fue MO. Los hallazgos microscópicos de la biopsia incisional revelaron una proliferación de células pleomórficas densamente pigmentadas, invadiendo difusamente el tejido conectivo en forma de sábanas o nidos con patrón organoide. La positividad inmunohistoquímica para S-100, Melan-A y HMB-45 confirmó el diagnóstico de melanoma. El paciente fue referido a un hospital oncológico, en el cual se le detectaron múltiples metástasis y fue sometido a cuidados paliativos. Este es el reporte de un caso de MO diagnosticado en estado avanzado, en el que se discuten los criterios clínicos, morfológicos e inmunohistoquímicos para su diagnóstico, haciendo énfasis en la importancia del diagnóstico temprano.

PALABRAS CLAVE: cáncer de cabeza y cuello, melanoma, melanoma oral. 


\section{REFERENCES}

Ascierto, P. A.; Accorona, R.; Botti, G.; Farina, D.; Fossati, P; Gatta, G.; Gogas, H.; Lombardi, D.; Maroldi, R.; Nicolai, P.; et al. Mucosal melanoma of the head and neck. Crit. Rev. Oncol. Hematol., 112:136-52, 2017.

Caldeira, P. C.; de Sousa, S. F.; Gomez, R. S. \& Silva, T. A. Diffuse pigmentation of the oral mucosa. Oral Surg. Oral Med. Oral Pathol. Oral Radiol. Endod., 110(5):550-3, 2010.

Deyhimi, P.; Razavi, S. M.; Shahnaseri, S.; Khalesi, S.; Homayoni, S. \& Tavakoli, P. Rare and extensive malignant melanoma of the oral cavity: report of two cases. J. Dent. (Shiraz), 18(3):227-33, 2017.

Eachempati, P.; Aggarwal, H.; Shenoy, V. K. \& Baliga, M. Multidisciplinary approach for management of a patient with oral mucosal malignant melanoma. J. Coll. Physicians Surg. Pak., 28(9):S187-9, 2018.

El-Naggar, A. K.; Chan, J. K. C.; Grandis, J. R.; Takata, T. \& Slootweg, P. J. WHO Classification of Tumours. Pathology and Genetics of Head and Neck Tumours. $4^{\text {th }}$ ed. Lyon, IARC Press, 2017.

Gondak, R. O.; da Silva-Jorge, R.; Jorge, J.; Lopes, M. A. \& Vargas, P. A. Oral pigmented lesions: Clinicopathologic features and review of the literature. Med Oral. Patol Oral. Cir. Bucal, 17(6):e919-24, 2012.

Hsieh, R.; Nico, M. M.; Camillo, C. M.; Oliveira, K. K.; Sangueza, M. \& Lourenço, S. V. Mutational status of NRAS and BRAF genes and protein expression analysis in a series of primary oral mucosal melanoma. Am. J. Dermatopathol., 39(2):104-10, 2017.

Liu, C. H.; Lin, C. H.; Tsai, M. J.; Chen, W. T.; Chai, C. Y.; Huang, Y. C. \& Tsai, K. B. Melanin bleaching with dilute hydrogen peroxide: a simple and rapid method. Appl. Immunohistochem. Mol. Morphol., 21(3):275-9, 2013.

Moshe, M.; Levi, A.; Ad-El, D.; Ben-Amitai, D.; Mimouni, D.; Didkovsky, E.; Feinmesser, M. \& Lapidoth, M. Malignant melanoma clinically mimicking pyogenic granuloma: comparison of clinical evaluation and histopathology. Melanoma Res., 28(4):363-7, 2018.

Schaefer, T.; Satzger, I. \& Gutzmer, R. Clinics, prognosis and new therapeutic options in patients with mucosal melanoma: $A$ retrospective analysis of 75 patients. Medicine (Baltimore), 96(1):e5753, 2017.

Smith, M. H.; Bhattacharyya, I.; Cohen, D. M.; Islam, N. M.; Fitzpatrick, S. G.; Montague, L. J.; Damm, D. D. \& Fowler, C. B. Melanoma of the oral cavity: an analysis of 46 new cases with emphasis on clinical and histopathologic characteristics. Head Neck Pathol., 10(3):298-305, 2016.

Topic, B.; Mas`ic', T.; Radovic. S.; Lincender, I. \& Muhic, E. Primary oral mucosal melanomas - Two case reports and comprehensive literature review. Acta Clin. Croat., 56(2):323-30, 2017.
Corresponding author:

Prof. Silvia Ferreira de Sousa

Department of Oral Surgery and Pathology

School of Dentistry

Universidade Federal de Minas Gerais

Av. Antonio Carlos, 6627

Pampulha

CEP 31270-901

Belo Horizonte

BRAZIL

Email: silviafsousa@ufmg.br

Received: 18-12-2018

Accepted: 08-02-2019 